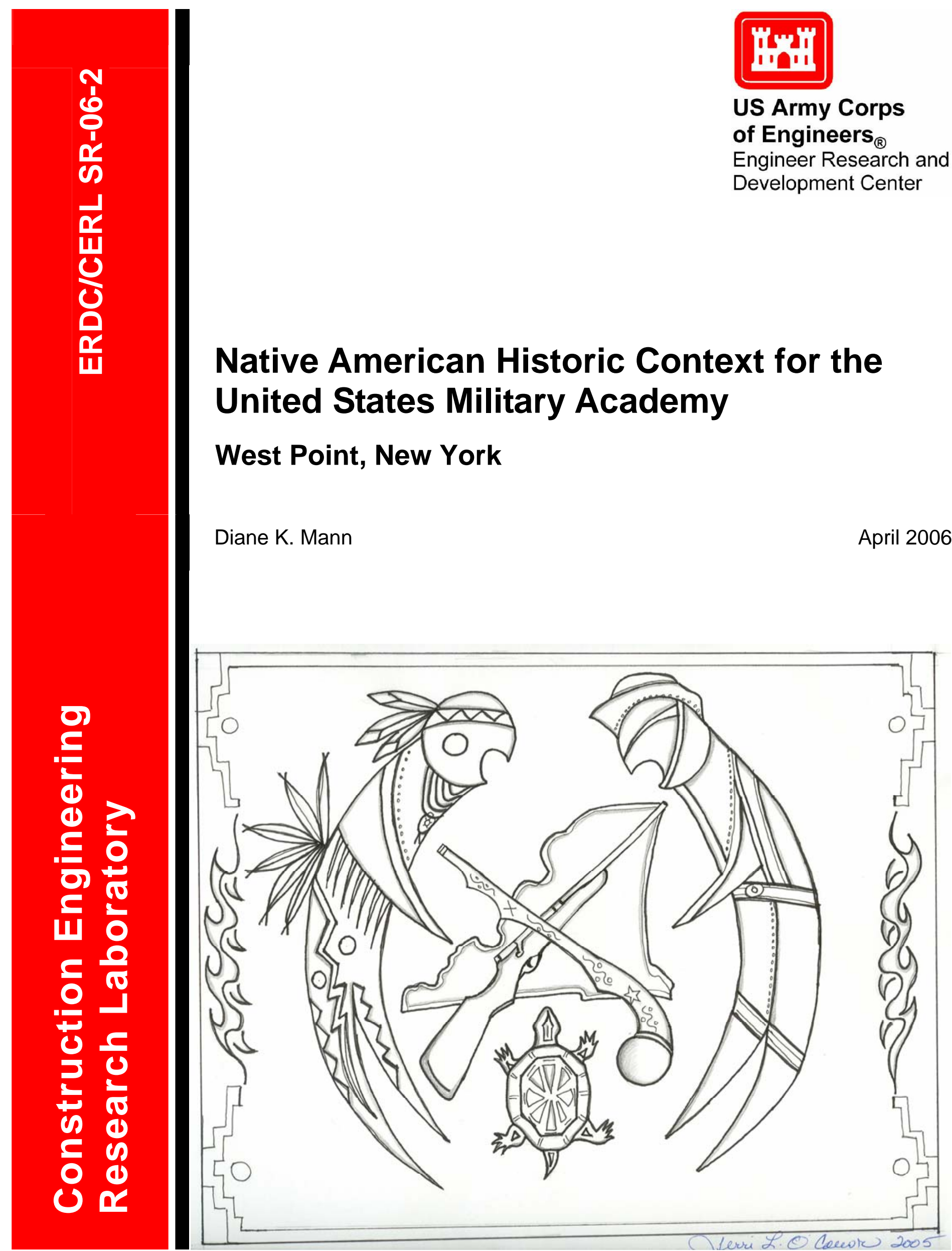




\section{Native American Historic Context for the United States Military Academy: \\ West Point, New York}

Diane K. Mann

Construction Engineering Research Laboratory

PO Box 9005

Champaign, IL 61826-9005

Final Report

Approved for public release; distribution is unlimited.

Prepared for United States Military Academy

West Point, New York 10996

Under

Work Unit \#4FDK42 
ABSTRACT: The United States Military Academy (USMA) is required by Federal laws, Executive Orders, and implementing regulations to conduct consultations with Native American tribes under specific circumstances. This historic context was prepared to support the preparation of a Native American Consultation program at the USMA by identifying the appropriate Indian tribes with whom consultation should take place.

This report discusses historic periods and possible archeological sites near the USMA. It contains a brief history of various Native American nations that may have been living in or using the West Point vicinity and the Hudson Highlands at initial contact with Europeans and discusses early interactions between Europeans and the Native American nations in the Hudson Valley. This report also specifically identifies the appropriate Native American Federally recognized tribes and communities, and other appropriate Native American organizations and entities with which the USMA should consult. Recommendations for the consultation protocol are included.

DISCLAIMER: The contents of this report are not to be used for advertising, publication, or promotional purposes. Citation of trade names does not constitute an official endorsement or approval of the use of such commercial products. All product names and trademarks cited are the property of their respective owners. The findings of this report are not to be construed as an official Department of the Army position unless so designated by other authorized documents. 


\section{Preface}

This study was conducted for the United States Military Academy under Military Interdepartmental Purchase Request MIPR5ECLR50055, "Implement Native American Consult Program for Michie Stadium." The technical monitor was Douglas R. Cubbison, Cultural Resources Manager.

The work was performed by the Land and Heritage Conservation Branch (CN-C) of the Installations Division (CN), Construction Engineering Research Laboratory (CERL). The CERL Principal Investigator was Dr. Diane K. Mann. Dr. Lucy Whalley is Chief, CEERD-CN-C, and Dr. John T. Bandy is Chief, CEERD-CN. The associated Technical Director was Dr. William D.

Severinghaus, CEERD-CV-T. The Acting Director of CERL is Dr. Ilker R. Adiguzel.

CERL is an element of the U.S. Army Engineer Research and Development Center (ERDC), U.S. Army CorpMilitary Interdepartmental s of Engineers. The Commander and Executive Director of ERDC is COL James R. Rowan, and the Director of ERDC is Dr. James R. Houston.

This report will be made accessible through the World Wide Web (WWW) at URL: http://www.cecer.army.mil 


\section{Contents}

\section{Preface}

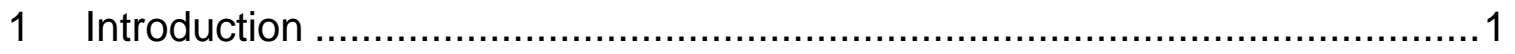

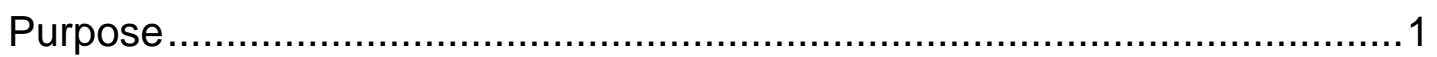

2 Native Americans in the Hudson Highlands Pre-Contact Period ..................2

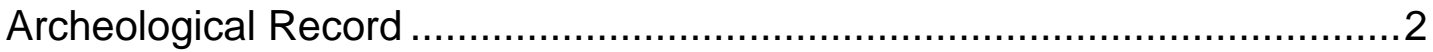

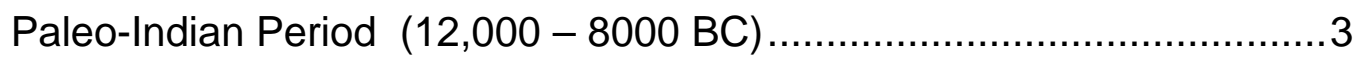

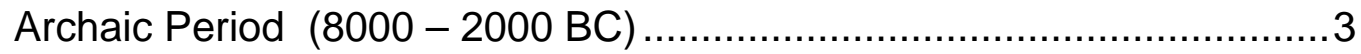

Woodland Period (2000 BC - 1000 AD) ……................................ 5

Proto-historic Period (1000 - 1800 AD) ........................................

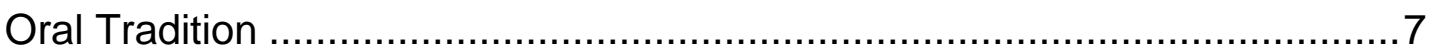

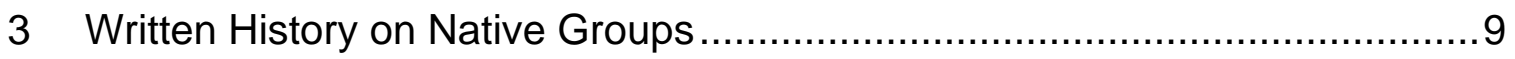

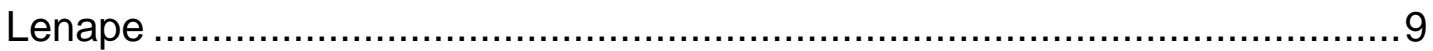

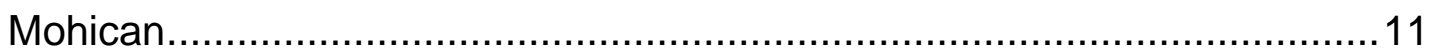

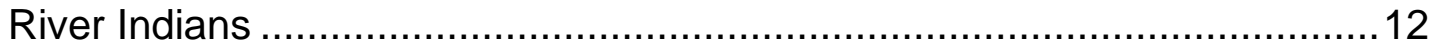

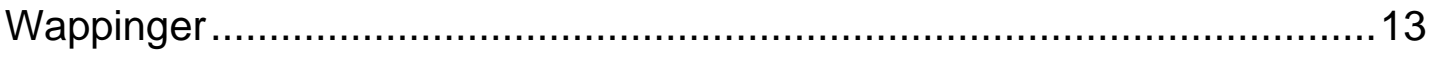

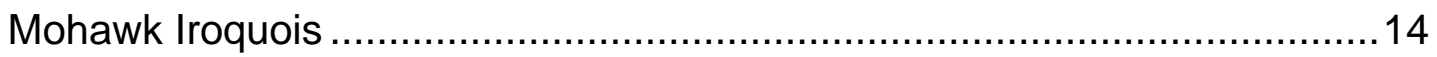

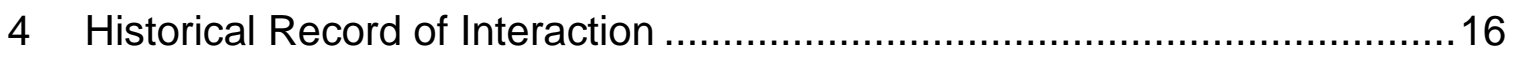

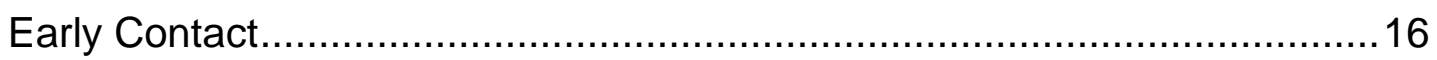

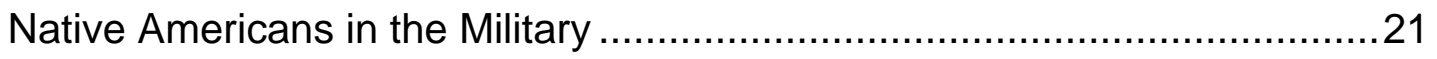

5 Consultation with Federally Recognized Tribes .....................................24

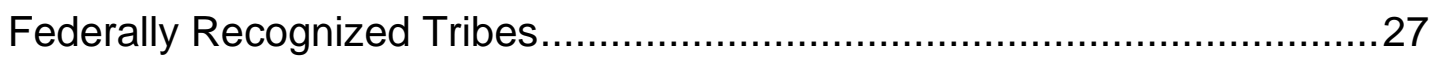

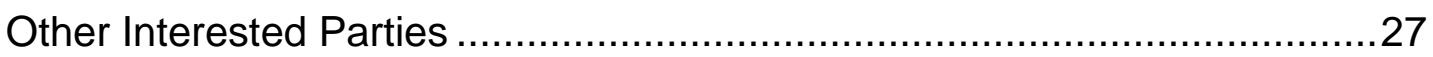

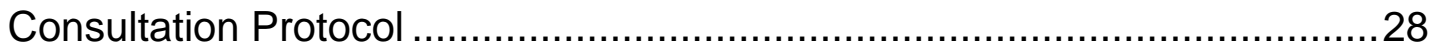

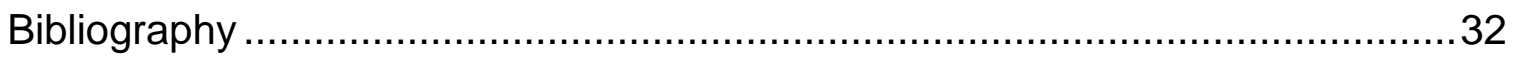

Appendix A: Related Federal Laws, Orders, and Information ..........................38

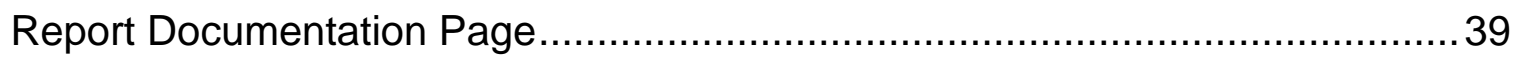




\section{Introduction}

The United States Military Academy (USMA) is required by Federal laws, Executive Orders, and implementing regulations to conduct consultations with Native American tribes under specific circumstances. To support the preparation of a Native American Consultation program at the USMA, it is first necessary to identify the appropriate Indian tribes with whom consultation should take place.

Chapter 2 discusses historic periods and possible archeological sites. Chapter 3 contains a brief history of various Native American nations that may have been living in or using the West Point vicinity and the Hudson Highlands at initial contact with Europeans (c. 1609). Chapter 4 discusses early interactions between Europeans and the Native American nations in the Hudson Valley. Chapter 5 specifically identifies the appropriate Native American Federally recognized tribes and communities, and other appropriate Native American organizations and entities with which the USMA should consult. This chapter also includes recommendations for the consultation protocol.

\section{Purpose}

This report is designed to assist staff of the USMA in consultations with Federally recognized Native American tribes, and appropriate Native American interested parties, in regulatory compliance with Federal laws, Executive Orders, and implementing regulations; and particularly with the Native American Graves Protection and Repatriation Act (NAGPRA) of 1990. 


\section{Native Americans in the Hudson Highlands Pre-Contact Period}

A number of American Indian nations have over time either occupied the Hudson Valley region of New York State or used the Hudson Highland region (including the present area of the USMA) for hunting, fishing, gathering, trade, or travel.

\section{Archeological Record}

Accurately connecting an archeological record to historically recognized tribes is seldom accomplished. A direct correlation exists between elapsed time and identification with tribal names; as the archeological record goes back in time, probable connections quickly diminish to zero. Furthermore, tribal names recorded in historical documents reflect European interpretation, confused spellings, and vested interests. Created tribal names are related to conditions and geographical locations in the period of time when they were assigned to groups of people; they rarely reflect the tribes' world view, long-term relationships to each other, and their earliest roots.

Consequently, major classifications have been devised that deal with early Indian cultures in generalized terms based on diagnostic traits. These classifications with approximate dates include: Paleo-Indian (12,000 - 8000 BC), Archaic (8000 - 2000 BC), Woodland (2000 BC - 1000 AD) and Proto-historic (1000 - 1800 AD).

In turn, these major classes or eras are subdivided into early, middle, and late periods with culture names based on locally recognized traits. Dates assigned to periods vary geographically. A classification system is a tool to organize and interpret available data and not a record of events. Consequently, changes are made continually and classifications evolve as more data become available. Applying classification as a tool to the area where the USMA is located provides a framework for attaching and interpreting current data. However, at this time, archeological data specific to the area is limited, with extensive time gaps. 


\section{Paleo-Indian Period (12,000 - 8000 BC)}

The Paleo-Indian Period of the Pleistocene begins with the arrival of man in the Americas. These people were highly mobile, ranged over large areas, and used a range of biota, including now-extinct large mammals. No Paleo-Indian sites have been identified to date at the USMA. However, Paleo-Indian sites have been identified in the Hudson Highlands; two sites are near the USMA. The Dutchess Quarry Cave ${ }^{1}$ near Florida in Orange County is 15 miles west of the USMA and the Twin Fields site in Dwaar Kill in Ulster County is 27 miles to the northwest. PaleoIndian groups roamed over large areas to hunt and gather. Most likely they ranged over the USMA land, but these early sites either have not been located or have been destroyed over time.

\section{Archaic Period (8000 - 2000 BC)}

The beginning of the Archaic Period roughly corresponds to the beginning of the Holocene and a warmer climate. Band-level groups increasingly used foraging strategies and ranged over smaller areas. John Mohawk, Seneca, gives an appropriate description. ${ }^{2}$

By about 10,000 years ago, people were organized in groups of perhaps 500 people occupying about 300 square miles, moving from camp to camp, following the food supply through the season.

\footnotetext{
${ }^{1}$ Robert E. Funk, George R. Walters, William F. Ehlers, Jr., John E., Guilday, and G. Gordon Connally, 1969, “The Archeology of Dutchess Quarry Cave, Orange County, New York,” Pennsylvania Archeologist 39(1-4):7-22; Robert E. Funk, George R. Walters, and William F. Ehlers, Jr., 1969, “A Radiocarbon Date for Early Man from the Dutchess Quarry Cave,” New York State Archaeological Association Bulletin 46 (July):19-21. Rochester, NY; Robert E. Funk, Donald W. Fisher, and Edgar M. Reilly, Jr., 1970, "Caribou and Paleo-Indian in New York State: A Presumed Association,” American Journal of Science 268(2):181186; John E. Guilday, 1969, “A Possible Caribou-Paleo-Indian Association from Dutchess Quarry Cave, Orange County, New York.” New York State Archaeological Association Bulletin 44:24-29. Rochester.

${ }^{2}$ John Mohawk, Indian Country Today, "Indigenous Rights Must Become a Priority” September 22, 2004 Vol 24, No. 15.
} 
Estimate of group size may be large for this early date and groups would have been made up of small bands of related members. ${ }^{3}$

Several Archaic sites are located near the USMA. Early Archaic materials are included in a stratified sequence at the Muddy Brook Rockshelter ${ }^{4}$, which is in Putnam County, across the Hudson River from West Point. West Point contains 178 archaeological sites, of which approximately 50 are prehistoric. Of West Point's 16,000 acres, approximately 14,600 acres are available for survey (excluding water areas, wetlands, and impact areas). Only 15 percent of West Point has been surveyed for cultural resources, and it is anticipated that several hundred prehistoric sites are probably located at West Point. Typically, West Point's prehistoric sites are consistent with small fishing or hunting sites, and they are typically rock shelter or camp sites located in close proximity to water resources.

The John Robinson II Prehistoric site in Newburgh, Orange County, near the Stewart International Airport is a Late Archaic site. ${ }^{5}$ A component at the Datum site near Kingston is also Late Archaic. ${ }^{6}$

A few Archaic sites have been identified at the USMA. USMA ICRMP (Integrated Cultural Resources Management Plan) Site \# $7^{7}$ at the Marine Battery is dated from the Late Archaic. A rockshelter at Crow's Nest Mountain Shelter (New York State Museum [NYSM] \#8097) also dates to the Late Archaic. The USMA ICRMP Site \#12 at Redoubt \#4 (on Patrick Trail in the Stony Lonesome Housing Area) contains a Late Archaic component. The Garrison site (NYSM Site \#546, across the Hudson River from West Point) and Bear Mountain Museum site (south of West Point) were

\footnotetext{
${ }^{3}$ Marshall Joseph Becker, 1993, “The Lenape and Other "Delawarean” Peoples at the Time of European Contact: Population Estimates Derived from Archaeological and Historical Sources.” Bulletin and Journal of Archaeology for New York State, 105.

${ }^{4}$ R. Curt Tompkins and Laurie DiMaria, 1979, "Excavations at Muddy Brook Rockshelter, 1975-1976: A Progress Report.” New York State Archaeological Association Bulletin 75:58-63.

${ }^{5}$ Edward V. Curtin, 1987, John Robinson I Historic Site and John Robinson II Prehistoric Site. Archaeological Data Recovery Report, PIN 8914.16.101. New York State Museum, Albany, NY.

${ }^{6}$ Leonard Eisenberg, 1980, A Cultural Resources Survey of the Proposed Lake Frederick Drop Zone and Indoor Athletic Facility Sites, U.S. Military Academy, West Point, New York. Report on file at the United States Military Academy, West Point.

${ }^{7}$ To protect the sites, their precise location is confidential.
} 
occupied starting in the Late Archaic. A rockshelter near Bog Meadow Pond named the Bog Meadow Rockhouse (ICRMP-062) that produced several hundred artifacts is judged to have been occupied during the Transitional Period that joins the end of the Archaic Period and the beginning of the Woodland Period. ${ }^{8}$

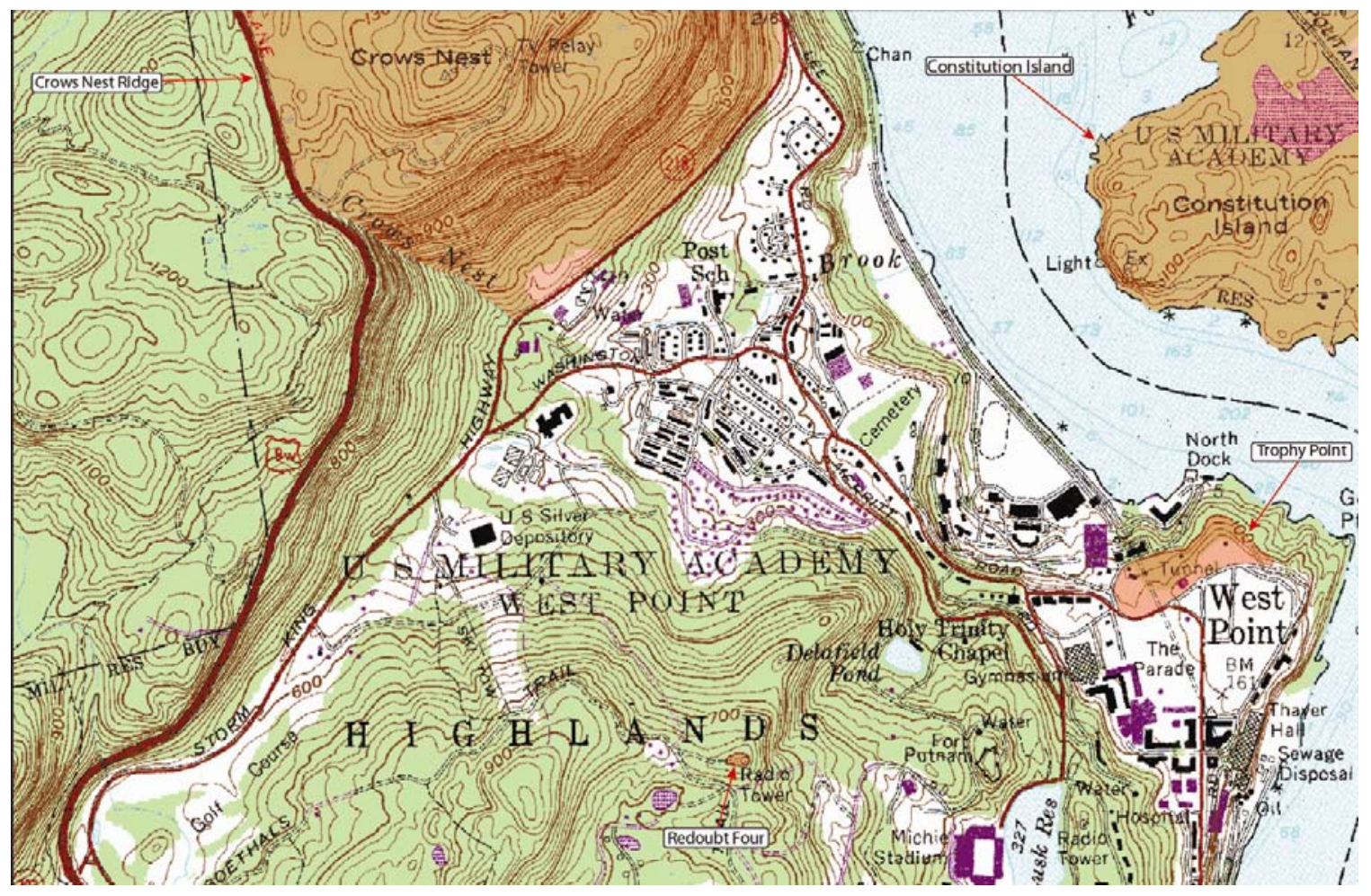

Figure 1. Map of USMA area.

\section{Woodland Period (2000 BC - 1000 AD)}

The Woodland Period began with a climate somewhat colder than the preceding period, but during later phases of the 3000-year period, climatic conditions fluctuated between warmer and cooler. Population increases continued from the previous period with fairly complex societies and exchange networks. Pottery is the critical diagnostic trait used for this period and plant domestication was widespread.

\footnotetext{
${ }^{8}$ Max Schrabisch, 1936, “Archaeology of Southern New York” (Unpublished manuscript on file at New York State Museum).
} 
Sites identified near the USMA as Woodland sites, but not more specific, include the Riverbank Rockshelter (Wpt 16) near the town of Fort Montgomery ${ }^{9}$ and the Doodletown Rockshelter (Wpt 10) located on Doodletown Brook south of the USMA. Woodland sites on Constitution Island without more specific identifications are Marine Battery (ICRMP-002.10) and Roman's Battery (ICRMP-002.02).

\section{Early Woodland}

Habitation sites in New York and southern New England identified as Early Woodland are very scarce. The Scaccia site has small features and refuse pits and the Nahrwold No.2 site has pits features of refuse deposits. ${ }^{10}$ Possibly the Dennis site located near the USMA is from this period. ${ }^{11}$ Artifacts and remains suggest that hunting, fishing, and gathering were done by these early small groups. Although there is little definitive information, it has been suggested that habitation sites near large streams and lakes may have been preferred.

\section{Middle Woodland}

During this period a hunt/gather strategy was still being used by small groups consisting of kinfolk who moved from one location to another during the year to capitalize on seasonal resources. Occupation at the Torne Mountain Rockshelter located 2 miles northeast of the village of Rampo probably began in Middle Woodland times. ${ }^{12}$ Trophy Point (ICRMP-058) may be a Middle-Late Woodland site. Although the Torne Mountain Rockshelter site is likely from this period, analysis of Middle Woodland sites suggests that the majority of the sites were located on high bluffs overlooking the main branch or tributaries of the Hudson River. ${ }^{13}$

\footnotetext{
${ }^{9}$ Robert E. Funk, 1976, Recent contributions to Hudson Valley Prehistory. New York State Museum Memoir 22, Albany, NY.

${ }^{10}$ William A. Ritchie and Robert E. Funk, 1973, Aboriginal Settlement Patterns in the Northeast. New York State Memoir 20, Albany, NY.

${ }^{11}$ Funk, 1976.

12 Schrabisch, 1936.

13 Funk, 1976.
} 


\section{Late Woodland}

The Late Woodland Period is associated with maize horticulture. Again, there is limited information on these late prehistoric sites in the Hudson Valley. Available information suggests that maize horticulture and its related new tools may have occurred about 100 years later in the Hudson River Valley compared to other New York areas. ${ }^{14}$ Based on available information from the Hudson River Valley, these late prehistoric sites were located along river floodplains.

\section{Proto-historic Period (1000 - 1800 AD)}

Warmer climate conditions and cultural developments favored agriculture during most of the Proto-historic era. However, the later part of this era was considered less favorable to agricultural populations. Some evidence indicates increased warfare and settled nucleation (concentrations of people in larger communities) during this period. Monumental construction occurred over the Eastern Woodlands. ${ }^{15}$

No sites from this period have been documented on the USMA land, but use of resources in the area and trade along the Hudson certainly occurred.

\section{Oral Tradition}

Dialects spoken by the Lenape, the Mohicans, and the River Indians are all Algonquian languages. Their oral histories correspond in relating that their ancestors resided in the western part of the American continent and journeyed a great distance to the Mississippi River. Their accounts detail trials and conflicts with unfriendly occupants living near the Mississippi. These encounters led them to join forces temporarily with the Iroquois who were similarly traveling eastward in

\footnotetext{
${ }^{14}$ Daniel Cassedy, P. Webb, A. Dowd, J. Jones, C. Cobb, S. Dillon, M. Reinbold, and T. Millis, 1993, Iroquois Gas Transmission System, Phase III Archaeological Data Recovery Report, Volume 2, The Valley Region. Garrow and Associates, Inc., Atlanta, GA.

15 James B. Griffin, 1961, "Some Correlations of Climatic and Cultural Change in Eastern North American Prehistory,” Annals of the New York Academy of Sciences 95:710-717. New York.
} 
search of a new homeland. ${ }^{16}$ Eventually, some of the Lenape moved into the east. The Mohicans separated from this group and settled along the Hudson River.

Linguistic research indicates that Iroquoian-speakers had a homeland in the Appalachian uplands. ${ }^{17}$ However, oral tradition relates a movement from the west and across the Mississippi River. Some time after Algonquian settlement of a vast area that expanded out from the eastern Great Lakes, Iroquoian migrations intruded into the middle of the area. As a result of this migration, a permanent separation occurred between the Central and Eastern Algonquian language groups. ${ }^{18}$

${ }^{16}$ Shirley W. Dunn, 1994, The Mohicans and Their Land 1609-1730. Purple Mountain Press, Fleischmanns, NY.

${ }^{17}$ Stuart J. Fiedel, 1987, “Algonquian Origins: A Problem in Archeological-Linguistic Correlation.” Archaeology of Eastern North America, 15:1-11; Stuart J. Fiedel, 1991, "Correlating Archaeology and Linguistics: The Algonquian Case.” Man in the Northeast, 41:9-32; Stuart J. Fiedel, 1999, “Algonquians and Iroquoians: Taxonomy, Chronology, and Archaeological Implications," pp 193-204 in Taming the Taxonomy: Toward a New Understanding of Great Lakes Archeology, edited by R. F. Williamson and E. M. Wafts, The Ontario Archeological Society, Inc. and Eastend Books, Toronto; and Stuart J. Fiedel, 2001, "What Happened in the Early Woodland?” in Archaeology of Eastern North America 29:101-142.

${ }^{18}$ Ives Goddard, 1978, “Central Algonquian Languages," in Handbook of North American Indians, Volume 15, The Northeast, edited by B.G. Trigger, Smithsonian Institution, Washington, DC; Fiedel 1987, 1991, 1999, 2001. 


\section{Written History on Native Groups}

As early as 1630 it was recognized that three great divisions or nations were represented on the Hudson: the Iroquois, Mohicans, and Lenni Lenapes. ${ }^{19}$ At the time of European contact in the Hudson Valley, Native inhabitants of the area were recorded with a host of names, but distinct descriptions were lacking. Descriptive accounts written at the time failed to distinguish such distinct groups as the Mohawks and the various nations of River Indians living along the Hudson. ${ }^{20}$ Distinctions were often blurred and overlapping, especially regarding Indian groups assigned to the "Delaware Nation." This was done according to European interpretation of native organization and had little relationship to the Indian worldview and their history. It has been argued that the ethnic and linguistic landscape observed by Europeans arriving on the scene represented nothing more than a temporary accommodation. ${ }^{21}$ Subsequent relating of the area's history has attempted to weave a whole cloth out of a tangle of misconception.

\section{Lenape}

Natives who lived along the banks of the Delaware River and in the area drained by its tributaries called themselves Lenni Lenape. The element 'len' present in both words means "common" and 'ape' means "people," thus doubly translating to "common people." The homeland of these Indians includes New Jersey, Delaware, southeastern Pennsylvania lying between the Susquehanna and Delaware rivers, and the southeastern part of New York State west of the Hudson River. Each Lenni Lenape village was an independent community. Bands were made up of villages along a stream and frequently used the stream name as the band name. ${ }^{22}$ The concept that the Lenni Lenape was a political entity, a "Delaware Nation" with a single recognized authoritative leader was an expedient creation of Europeans.

\footnotetext{
${ }^{19}$ E.M. Ruttenber, 1872, History of the Indian Tribes of Hudson's River. J. Munsell, Albany, NY.

${ }^{20}$ Dunn 1994.

${ }^{21}$ John P. Hart and Hetty Jo Brumbach, 2003, “The Death of Owasco.” American Antiquity 68(4):737-752.

${ }^{22}$ Clinton A. Weslager, 1972, The Delaware Indians: A History. Rutgers University Press, New Brunswick, New Jersey.
} 
One of the most northern communities of the Lenape in early records is Minisink. It was located in present New Jersey on the Delaware River slightly southwest of where the Delaware River forms the boundary between New Jersey and New York. The name Minisink came to be applied to an extensive area and residents of these northernmost communities were later called Munsies and spoke a different dialect than communities further to the south. ${ }^{23}$ All Delaware dialects fall within the Algonquian language group.

Perhaps the Munsies are best considered a tribal affiliate of the Delaware Nation. Both the Munsies and the Lenape/Delaware have been divided, co-mingled, and scattered. James Mooney estimated in 1907 that 260 Munsies were living with the Stockbridges in Wisconsin, 45 Munsies were living with the Chippewa in Kansas, and 122 "Munsies of the Thames," were living in Ontario. ${ }^{24}$ The StockbridgeMunsee Community Band of Mohicans in Wisconsin, which included the 260 Munsies according to Mooney's 1907 estimate, gained Federal recognition in 1937. Membership was limited to those persons whose names appeared on a Stockbridge Indian Allotment Roll of 1910 and were residing within the original confines of the Stockbridge Reservation in Shawano County, Wisconsin, when their Constitution and By-Laws were adopted. Their Algonquian dialect has become extinct among the Stockbridge-Munsee in Wisconsin. Most of the original admixture of this community came from New York and New England and were joined later by additional Munsie families. ${ }^{25}$ Mohicannittuck is one of the spellings for the Indian name for the Hudson River and the source for the name Mohican. Subtribal designations of the Delware used by early European settlers were geographical terms.

Minsi (Monseys, Montheys, Munsies, or Minisinks), properly Minsiu, and formerly Minassiniu, means "people of the stony country" or briefly

\footnotetext{
${ }^{23}$ Weslager, 1972.

${ }^{24}$ James Mooney, 1907, “Delaware,” pp 385-387 in Vol 1 of Handbook of American Indians North of Mexico, Frederick W. Hodge, ed. 2 vols. Bureau of American Ethnology Bulletin 30, Washington, DC.

${ }^{25}$ Weslager, 1972.
} 
"mountaineers." It is a synthesis of menthe, "to be scattered," and achsin,

"stone," according to the best living native authorities. ${ }^{26}$

As remnant bands moved from their rugged homeland to settle new areas, Minsi or Munsee, which differentiated one of the dialects, was used in a political sense referring to separate groups. It was used for bands living in greater New York, western Long Island, Rockland, Orange, and Westchester counties, northern New Jersey, and the great area of the Hudson Highlands that is now the Palisades. In the contact period, northernmost Munsee communities closely affiliated themselves with New Yorkers and came to be called "New York Indians."27

\section{Mohican}

Spellings used to designate Native Americans residing in the upper Hudson region, eastern Mohawk Valley, and the Housatonic Valley include Mohican, Mahikan, Mahiecan, Maykan, Muhheakunn, Moheakun, and Mohegan. Mahican was the most common form in the 17th century; but after that, Mohican became the most popular spelling. ${ }^{28}$ To further confuse the issue, James Fennimore Copper in his popular story about the Mohegans or Morhingans of Connecticut used the name Mohican.

Mohican territory at the time of European contact extended from Lake Champlain southward into the western part of Dutchess County, New York, and from the valley of the Schoharie Creek in the west to south-central Vermont in the east. ${ }^{29}$

However, descendants of the Mohicans believe their ancestors ranged all along the Hudson River down to Manhattan. Sherry White who heads the Cultural Preservation Office of the Stockbridge Munsee Community Band of Mohicans in Wisconsin provided a copy of the following speech (Professional Communication, 10 August 2004).

\footnotetext{
${ }^{26}$ Daniel G. Brinton, 1885, The Lenape and Their Legends; with Complete Text and Symbols of the Walam Olum, a New Translation, and an Inquiry into its Authenticity. Library of Aboriginal American Literature 5, Philadelphia.

${ }^{27}$ Robert S. Grumet, 1995, Historic Contact. University of Oklahoma Press, Norman and London.

28 Dunn, 1994.

${ }^{29}$ Louis Brasser, 1978, “Mahican” in Handbook of North American Indians, edited by Bruce Trigger, Volume 15. Smithsonian Institution Press, Washington, DC.
} 
"The people of the waters that are never still"

John W. Quinney, a Muh-he-con-new, gave a speech at a celebration of the Fourth on July in 1854 at Reidsville, New York.

The tribe, to which your speaker belongs, and of which there were many bands, occupied and possessed the country from the seashore, at Manhattan, to Lake Champlain. Having found an ebb and flow of the tide they said: "This is Muh-he-con-new"- "like our waters, which are never still." From this expression, and by this name, they were afterwards known until their removal to Stockbridge, in the year 1730. Housatonic River Indians, Mohegan, Manhattas, were all names of bands in different localities, but bound together as one family, by blood, marriage and descent.

This speech, oral traditions of the Mohicans, and written documents of early European governments that have survived, attest that the USMA lands were long used by Mohicans and closely related peoples derived from the same ancestors. Names and groupings depend upon the period of time and confusion abounds in sorting them out. John Heckewelder, a Moravian missionary during the last half of the $18^{\text {th }}$ century wrote:

This was the case of the Mahicanni or Mohicans, in the east, a people who by intermarriages had become a detached body, mixing two languages together and out of the two forming a dialect of their own: choosing to live by themselves, they had crossed the Hudson River, naming it Mahicannituck River after their assumed name and spread themselves over all that country which now composes the eastern states. New tribes again sprung from them who assumed distinct names ... ${ }^{30}$

\section{River Indians}

Although various peoples listed as River Indians were Munsee-speakers, their relationship to other Lenape groups and their ethnic entities at the time of

\footnotetext{
${ }^{30}$ John G.E. Heckewelder, 1819, “An Account of the History, Manners, and Customs of the Indian Nations, Who Once Inhabited Pennsylvania and the Neighbouring States," Transactions of the Committee of History, Moral Science and General Literature of the American Philosophical Society 1. Philadelphia.
} 
European contact are unclear. Scholarly research of early documents and maps on various ethnic groups in the Hudson Valley have made suggested associations for the USMA area that include: the Kichtawanks in northern Westchester County; the Nochpeen in the Hudson Highlands; the Esopus and their sub-groups the Waorancks, Warranawankongs, and others, who occupied the west side of the river from the Catskills and the highlands of West Point; and the Wappingers of Dutchess and Putnam counties. ${ }^{31}$

\section{Wappinger}

Wappinger means "Easterners" and is from the same root as Abnaki and Wampanoage. They were located on the east bank of the Hudson River from Manhattan Island to Poughkeepsie and the territory eastward to the lower Connecticut Valley. ${ }^{32}$ Several subdivisions or "Sachemships" are within an approximate 30-mile radius of West Point. They include the Kitchawank in the northern part of Westchester county beyond the Croton River and between the Hudson River and Connecticut; Nochpeem in the southern part of Dutchess County; Sintsink, between the Hudson, Croton, and Pocantico rivers; Tankiteke, mainly in Fairfield County between Five Mile River and Fairfield but extending inland to Danbury and even into Putnam and Dutchess counties in New York; and the Wappinger proper around Poughkeepsie in Dutchess County, New York.

The closest known Wappinger villages to West Point are Canopus, in Canopus Hollow, Putnam County, and Kekistonk, probably on the Hudson River, south of the highlands, in Putnam County (Nochpeem). ${ }^{33}$ In Dutchess County, the villages of Nochpeem and Pashquasheck (probably on the bank of the Hudson River) have been identified. Villages of Kitchiwank (near the mouth of the Croton River), Sackhoes

\footnotetext{
${ }^{31}$ Charles T. Gehring and William A. Starna, 1991, "Dutch and Indians in the Hudson Valley: The Early Period,” The Hudson Valley Regional Review; Goddard 1978; John R. Swanton, 1952, The Indian Tribes of North America. Smithsonian Institution Bureau of American Ethnology Bulletin 145; and Monique J. Tyndall, 2004, "Ridge Hill Yonkers, New York: Study of the Weckquasgeek Chieftancy and the Present Site Known as "Redge Hill” Unpublished Manuscript, Cultural Preservation Office, Stockbridge-Munsee Band of Mohican Indians.

${ }^{32}$ John R. Swanton, 1952, “The Indian Tribes of North America,” Smithsonian Institution Bureau of American Ethnology Bulletin 145.

${ }^{33}$ Swanton, 1952.
} 
(site of Peekskill), and Senasqua (at the mouth of Croton River) have been identified for the Kitchiwank Sachemdom in the northern part of Westchester County. The village of Ossingsing at the site of Ossining is also in Westchester County.

\section{Mohawk Iroquois}

Originally, the Five Nations of New York that comprised the Iroquois Confederacy included the Seneca, Cayuga, Onondaga, Oneida, and Mohawk. The Tuscarora, who came north from Carolina, formally joined in 1722. ${ }^{34}$ Membership in the earliest confederacy most likely involved agreement among tribes to suppress blood feuds and cease raiding. The five tribes probably joined late in the $16^{\text {th }}$ century. ${ }^{35}$

In late prehistoric times, land used by the five Iroquois tribes stretched across upper New York State as far as the Mohawk River Valley. Tribal clusters of settlements were separated from one another by extensive tracts of hunting and fishing territory; higher inland regions were uninhabited and used for hunting. ${ }^{36}$ Towns were usually moved every 10 to 20 years to new locations short distances away. ${ }^{37}$ Relocation was dictated by exhaustion of soil, diminishment of the firewood supply, and environment problems associated with occupational clutter. ${ }^{38}$

As the most eastern member of the confederacy, the Mohawks were the nearest to the Hudson River. Their various roles when colonists met them were "Keepers of the Eastern Door," "Elder Brothers," and "People of the Flint". ${ }^{9}$ Their use of the Hudson Highlands and the Hudson River varied with relationships and the strength

\footnotetext{
${ }^{34}$ William N. Fenton, 1978, “Northern Iroquoian Culture Patterns,” in “Northeast,” edited by Bruce G. Trigger, pp 296-321 in Handbook of North American Indians, vol. 15, William C. Sturtevant, general editor. Smithsonian Institution, Washington DC.

${ }^{35}$ William N. Fenton, 1961, "Iroquoian Culture History: A General Evaluation in Symposium on Cherokee and Iroquois Culture,” William N. Fenton and John Gulick, eds., Bureau of American Ethnology Bulletin 180, Washington, DC.

${ }^{36}$ Bruce G. Trigger, 1978, “Early Iroquoian Contact with Europeans” in "Northeast”, edited by Bruce G. Trigger, pp. 344-356 in Handbook of North American Indians, vol. 15. William C. Sturtevant, general editor, Smithsonian Institution, Washington DC.

${ }^{37}$ C.M. Sykes, 1980, “Swidden Horticulture and Iroquoian Settlement,” Archaeology of Eastern North America 8:45-52.

${ }^{38}$ Fenton, 1978.

39 Mary Rowell Carse, 1943, The Mohawk Iroquois. MS thesis, Anthropology Department, Yale University.
} 
of their neighbors claiming those areas for their own use. ${ }^{40}$ Land use and political relationships of the Iroquois Confederacy at the time of European contact were quickly altered and linked to the politics and economics of the newcomers.

${ }^{40}$ George T. Hunt, 1960, The Wars of the Iroquois: A Study in Intertribal Trade Relations. University of Wisconsin Press, Madison, WI. 


\section{Historical Record of Interaction}

\section{Early Contact}

European contact in the Hudson Valley occurred in September 1609, when Dutch explorer Henry Hudson ascended the river that now bears his name and came to an area within sight of modern Albany, New York. At the time Hudson sailed up the river, three Native American nations maintained an interest in the west bank of the river. ${ }^{41}$ The Lenni Lenape, or Delaware, was established in numerous villages on the lower Hudson. These Delaware spoke in the Munsee (or Minsis) dialect. ${ }^{42}$ Orange County (New York) historian E.M. Ruttenber noted that a Minsis village was located near Cornwall, New York, establishing a northern boundary for Delaware influence that would have extended into the Hudson Highlands and West Point vicinity. ${ }^{43}$ The upper Hudson valley was occupied by the Mohican nation. Early Dutch trade was predominantly with the Mohican. In 1614, the Dutch followed Hudson's initial exploration, establishing a trading post near modern-day south Albany. ${ }^{44}$ The Dutch subsequently made two land purchases in the western upper Hudson Valley, in 1630 and 1631, from the Mohican. ${ }^{45}$ The third nation was the Mohawk tribe of the Iroquois Confederation. At European contact, the Mohawks

\footnotetext{
${ }^{41}$ This general interpretation is derived from E.M. Ruttenber, 1872, pp. 34-35.

${ }^{42}$ C. A. Weslager, 1972, p. 102; Julian Harris Salomon, 1982, Indians of the Lower Hudson Region, The Munsee. New City, New York: Historical Society of Rockland County, pp. 5, 14.

${ }^{43}$ Ruttenber, 1872, pp. 93-97, 218-222, 377-381.

${ }^{44}$ An interesting account of the linguistic challenges facing Hudson and the Native Americans he contacted is recounted in Lois M. Feister, 1973, "Linguistic Communication between the Dutch and Indians in New Netherland, 1609-1664,” Ethnohistory 20, Issue 1 (Winter 1973), pp. 25-38. The first Dutch trading post, Fort Orange, was located on the west bank of the Hudson just south of the future site of Albany.

${ }^{45}$ George T. Hunt, 1960, p. 31; Dean R. Snow, 1994, The Iroquois, Cambridge, Massachusetts and Oxford, United Kingdom: Blackwell Publishers p. 81; Daniel K. Richter, 1992, The Ordeal of the Longhouse, The Peoples of the Iroquois League in the Era of European Colonization, Chapel Hill: The University of North Carolina Press, pp. 53-55; and Bruce G. Trigger, 1971, “The Mohawk-Mahican War (1624-1628): The Establishment of a Pattern” Canadian Historical Review 52, No 3 (September 1971), p. 281. Trigger suggests that the Mahican were selling land from which they had been driven by the Mohawk, that they no longer occupied but "retained title for."
} 
were settled on the eastern portion of the modern Mohawk River. ${ }^{46}$ Trade with Native Americans in the Hudson Valley was apparently well established by 1624, for in that year Dutch kaolin smoking pipes and marine shell beads began to appear in Mohawk Indian sites. ${ }^{47}$ The Hudson Highlands appears to have served as a buffer zone that separated the three nations, or as a resource zone used by all three nations. ${ }^{48}$

Shortly after the establishment of Fort Orange by the Dutch in 1614, competition for the fur trade began to foster competition between the Mohawks, the Mohican, and the Delaware; a struggle in which the Mohawks would eventually emerge victorious. ${ }^{49}$ Fort Orange is the site of present-day Albany, approximately 60 miles north of West Point.

With the Mohican and Mohawk living in close proximity, and the Mohican placed to interdict Mohawk-Dutch trade, an inevitable conflict over access to and control of the European fur trade erupted between these two nations. Most sources suggest that the Mohawk nation, likely acting as an agent for the Iroquois Confederation, saw an early opportunity to engage in trade with the Europeans with the eventual aim of dominating the fur trade by serving as regional middlemen. For years the Mohawk had been engaged in a protracted struggle with the Algonquin Indians of the Saint Lawrence Valley to control the French fur trade. In 1622 the Mohawk had

\footnotetext{
${ }^{46}$ It should be noted that no Mohawk villages were located within the Hudson Highlands. All known $17^{\text {th }}$ century Mohawk villages are located within the confines of the Mohawk River Valley. For this, see Donald A. Rumrill, 1985, "An Interpretation and Analysis of the Seventeenth Century Mohawk Nation: Its Chronology and Movements” The Bulletin and Journal of Archaeology for New York State Archaeological Society 90 (1985), pp. 1-30; Donald A. Rumrill, 1991, "The Mohawk Glass Trade Bead Chronology: ca. 1560-1785” Beads, Journal of the Society of Bead Researchers 3 (1991), pp. 5-46; and David B. Guldenzopf, 1986, The Colonial Transformation of Mohawk Iroquois Society, State University of New York at Albany: PhD Thesis, pp. 14-25.

${ }^{47}$ Snow, 1994, pp. 79-80, 90. However, it should be noted that recent research suggests earlier MohawkDutch trade contacts. For this, refer to Wayne Lenig, 1999, "Patterns of Material Culture During the Early Years of New Netherland Trade.” Northeast Anthropology 58, Fall 1999, pp. 47-74.

${ }^{48}$ This is the premise of the USMA Cultural Resources Manager, and is deserving of considerably more study.

${ }^{49}$ It should be noted that this competition extended considerably beyond the Mohawk, Mohican, and Delaware nations and Fort Orange. These three nations were combatants in the upper Hudson Valley region only. For a comprehensive discussion of this topic, refer to the exhaustive study by Francis Jennings, 1984, The Ambiguous Iroquois Empire, The Covenant Chain Confederation of Indian Tribes with English Colonies, New York: W. W. Norton \& Company.
} 
agreed to a truce with the Algonquin, finalizing a treaty in $1624 .{ }^{50}$ That year a vicious Mohawk-Mohican war erupted. ${ }^{51}$ In 1626 a small number of Dutchmen joined with the Mohican in a raid on the Mohawks. In an engagement with the Mohawk, three of the Dutchmen were captured and tortured to death. ${ }^{52}$ This defeat appears to have broken the Mohican resistance. By 1628, the Mohawk concluded the war by crushing the Mohican nation, forcing the Mohican to abandon the western bank of the Hudson River to the Mohawk. ${ }^{53}$ The Mohican relocated to the Connecticut River valley and the eastern bank of the Hudson. ${ }^{54}$ From that year well into the later part of the $18^{\text {th }}$ century (for approximately 150 years) the Mohawk nation, and through them the Iroquois Confederation, would control the Indian fur trade that flowed into Albany. ${ }^{55}$

Some Dutch accounts suggest that several of the more northern Delaware communities had been placed under the Mohawk sphere of influence early in the $17^{\text {th }}$ century. ${ }^{56}$ With the removal of the Mohican Indians from the western bank of the Hudson River in 1628, the Delaware most likely retreated to the south to the Delaware River valley (into modern Pennsylvania), attempting to distance themselves from the Mohawk. Not particularly warlike according to some accounts,

\footnotetext{
${ }^{50}$ Trigger, 1971, p. 279; and Jennings, 1984, pp. 48-50. Jennings, typically extremely cautious in utilizing secondary sources, relies upon Trigger's interpretation of the Mohawk-Mahican War and its ramifications. ${ }^{51}$ Trigger, 1971, p. 279.

${ }^{52}$ Variously reported. Per Trigger, 1971, a party of Dutchmen being defeated in 1626 with three captured and killed, appears to be most reliable. This date is originally provided in J. F. Jameson, (editor), 1909, "Wassenaer's Historical Verhael" in Narratives of New Netherland, 1609-1664, New York: Charles Scribner's Sons, pp. 84-85.

${ }^{53}$ Trigger, 1971, p. 281. This date is originally provided in Jameson, (editor), 1909, p. 89; and J.F. Jameson, (editor), 1909, “Letter of Reverend Jonas Michaelius,” in Narratives of New Netherland, p. 131. Concurring opinions are expressed by Donald Lenig, "Of Dutchmen, Beaver Hats and Iroquois" in Robert E. Funk and Charles F. Hayes III, editors, Current Perspectives in Northeastern Archaeology, Essays in Honor of William A. Ritchie (Researches and Transactions of the New York State Archaeological Association, Volume 17, no. 1, 1977), pp. 71-84; Karl H. Schlesier, "Epidemics and Indian Middlemen: Rethinking the Wars of the Iroquois, 1609-1653” Ethnohistory 23, No. 2 (Spring 1976), p. 132; and Gehring and Starna, 1991, pp. 1-25.

${ }^{54}$ Allen W. Trelease, 1960, Indian Affairs in Colonial New York: The Seventeenth Century, Cornell University Press, pp. 46-48; and Richter, 1992, pp. 55-56.

55 Trigger, 1971, p. 281. For concurring studies, see Howard Vernon, 1978, "The Dutch, The Indians and the Fur Trade in the Hudson Valley, 1609-1664" and Laurence M. Hauptman, 1978, "The Dispersal of the River Indians: Frontier Expansion and Indian Dispossession in the Hudson Valley" in Laurence M. Hauptman and Jack Campisi, editors, Neighbors and Intruders: An Ethnohistorical Exploration of the Indians of Hudson's Rivers, Ottawa: National Museums of Canada, 1978, 197-209 and 242-260.

${ }^{56}$ Weslager, 1972, p. 103.
} 
the northern elements of the Delaware nation were rapidly subjugated by the hostile Mohawk nation and Iroquois Confederation. Attacks by Seneca war parties on the Delaware were recorded in 1661. Another source notes that when William Penn arrived to establish Pennsylvania in 1682, the Delaware had already placed themselves under the protection of the Iroquois Confederation. With this act, the Iroquois had symbolically made the Delaware "women," precluding them from going to war, negotiating treaties, or even managing their own lands. ${ }^{57}$ By the middle of the $17^{\text {th }}$ century, the Delaware had clearly been driven from the Hudson Valley. ${ }^{58}$

Unfortunately for the Mohawk, by establishing themselves as the trading partners of the Dutch at modern Albany, they exposed themselves to smallpox and other debilitating European diseases. A smallpox epidemic reached the Mohawk in 1634, devastating the population. Some sources suggest a reduction in population from 7740 to 2830 (a nearly two-thirds mortality rate) in a period of probably less than 100 days. ${ }^{59}$ For all practical purposes, the pre-European Mohawk culture had been destroyed. The resultant Mohawk nation was to be significantly impacted by European cultures and technology.

Perhaps one of the best insights into the effect of European conflicts, the Revolutionary War, and the early years of the United States government, is the story of Coocoochee, a Mohawk woman born into the Bear Clan in about 1740 in an area southeast of Montreal, Canada. She married a Mohawk warrior and had one daughter and three sons. As early and firm allies of the British, the Mohawks were the controlling force over the northern tribes until 1770 when they were defeated by the colonists.

Reduced and scattered after their defeat, the Mohawks were incorporated into other Indian nations. Coocoochee and her family lived during this critical period for all eastern North American Indian people. This period spanned the French and Indian

\footnotetext{
${ }^{57}$ Ruttenber, 1872, discusses these negotiations between the Iroquois and Delaware at some length; pp. 6470.

${ }^{58}$ Weslager, 1972, pp. 103, 179-182.

59 Snow, 1994, pp. 94-100; Richter, 1992, pp. 58-60; and Dean R. Snow and Kim M. Lanphear, 1988, "European Contact and Indian Depopulation in the Northeast: The Timing of the First Epidemics." Ethnohistory 35, no. 1 (Winter 1988), p. 24.
} 
War between France and England (1754 - 1760), the American Revolution (1775 1783), and continuing Indian-White warfare in the territory northwest of the Ohio River until 1794. Helen Hornbeck Tanner (1979) reconstructed a biographical sketch of Coocoochee from basic information from Oliver M. Spencer. In July 1792, when he was 10 years old, Spencer was captured by Coocoochee's son, White Loon, along the Ohio River near present-day Cincinnati. Spencer lived with Coocoochee until February 1793, but maintained contact with her throughout his lifetime. ${ }^{60}$

Coocoochee's life was first disrupted as her original homeland along with Lake Champlain and the Hudson River became a great war road between the British at Albany and French forces at Montreal. To escape encroachment by settlers and battles between competing European powers, Coocoochee's family moved to Ohio to join the friendly camp of Shawnee chief Blue Jacket. A trained and skilled medicine woman, she was highly respected in the inter-tribal settlements and her advice was widely sought. ${ }^{61}$

Her husband and sons fought in various battles; her husband was mortally wounded in one of the raids on the Miami towns ordered by General Josiah Harmer. The widowed Coocoochee continued moving in search of a safe homeland. She felt that the aggressive newcomers from Europe would not be satisfied until all Indians who escaped their rifle fire were crowded northward to perish in the Great Ice Lake or westward to drown in the Great Western Sea. She interpreted that the Great Spirit was angry with red people, especially the Mohawk nation whose way of life and numbers had been drastically reduced by disease and warfare. Information gathered from her children indicates that she died early in the $19^{\text {th }}$ century before the War of $1812 .{ }^{62}$

\footnotetext{
${ }^{60}$ Helen Hornbeck Tanner, 1979, “Coocoochee: Mohawk Medicine Woman.” American Indian Culture and Research Journal 3(3):23-41.

${ }^{61}$ Julia White, Woman Spirit, Coocoochee - Mohawk, http://www.meyna.com/mohawk2.html. Accessed September 2005.

${ }^{62}$ White, http://www.meyna.com/mohawk2.html
} 


\section{Native Americans in the Military}

The first Army Ranger unit was formed by Robert Rogers at Lake George late in 1755, to serve as scouts for the British and American army then fighting against the French in the Seven Years War. Rogers documents the first participation of Stockbridge Mohicans with his Rangers on a scout to Fort St. Frederick at Crown Point in July 1756. Rogers employed a full company of Stockbridge Mohican Rangers in the 1756 campaign, commanded by Captain Jacob Nawnawampeteoonk (also spelled Naunauphtaunk), with other Stockbridge Mohican Indians serving as Commissioned Officers. Rogers referred to him simply as Captain Jacob. In 1759 new companies of Stockbridge Mohican Indians were recruited under Captain Lotridge, Captain Jacob, and his son Captain Jacob Cheeksaunkun, and participated in that year's campaigns that resulted in the British capture of Fort Ticonderoga and Fort St. Frederick at Crown Point; and in the raid on St. Francis. At the raid on St. Francis, the only Ranger killed was a Stockbridge Indian. Another Ranger Company participated in the 1760 campaign that finally captured Montreal, this time under a Lieutenant Solomon Uhhaunauwaunmut. Rogers called him Lieutenant Solomon. The proud and illustrious tradition of the United States Army Rangers was in large part created by warriors of the Stockbridge Munsee Tribe fighting alongside American and British soldiers commanded by Major Robert Rogers and Captain Jacob and Lieutenant Solomon.

During the American Revolutionary War many New England regiments contained Native Americans serving from their home communities. The largest contingent was the Stockbridge Mohicans drawn from western New England and New York. ${ }^{63}$

With the onset of the War for American Independence, the Stockbridge Nation almost immediately supported the American Patriots, and warriors of their nation are known to have arrived to participate in the Siege of Boston as early as August 1775. Members of the Stockbridge tribe were also busy assisting the Continental Congress with diplomacy with other Indian tribes, attempting to obtain either active

\footnotetext{
${ }^{63}$ Patrick Frazier, The Mohicans of Stockbridge, University of Nebraska Press, Lincoln., 1992.
} 
support for the Patriot cause, or at least neutrality. In 1776 a company of Stockbridge Indians served with the Continental Army at Fort Ticonderoga; members of this company are documented to have served as scouts with Benedict Arnold's Fleet at the Battle of Valcour Island on Lake Champlain in October $1776 .{ }^{64}$ During the Saratoga Campaign of 1777, another company of Stockbridge Mohicans commanded by Captain Abraham Nimham served with the Northern Army under General Horatio Gates, and contributed significantly to American victory by restricting British patrols from effectively scouting the American defensive positions and by keeping the British army in a state of nearly continual alarm.

Captain Abraham Nimham had applied to Congress in October of 1777 to serve the United States. He and his company of Indians were assigned to Major General Gates for duty. ${ }^{65}$ Captain Nimham was the son of Daniel Nimham, a respected Wappinger chief who moved to Stockbridge from the lower Hudson River. ${ }^{66}$ Most likely Nimham's company consisted mainly of Stockbridge Mohicans.

During the spring of 1778, Captain Nimham requested that Stockbridge men serving in a number of different Continental Army units, be permitted to organize into a single Stockbridge Company under his command. Apparently permission was given. It is believed that these men were initially organized at West Point and then joined the main Continental Army at White Plains.

By July 1778 Captain Nimham's company of Stockbridge Mohicans were serving with the Corps of American Light Infantry, performing scouting, reconnaissance, and various raiding and patrolling duties in Westchester County. The Indians proved extremely adept at this assignment, and were soon causing considerable problems for the British outposts in the county, much as they had the year before at Saratoga. On August 20, 1778, they succeeded in ambushing a party of Hessian

\footnotetext{
${ }^{64}$ Fraizer, 1992.

65 Thomas F. DeVoe, “The Massacre of the Stockbridge Indians, 1778” Magazine of American History V, no. 3, September 1880, 187-195.

${ }^{66}$ Richard S. Walling, 2004a, "Nimham's Indian Company of 1778: The Events Leading up to the Stockbridge Massacre of August 31, 1778” in Shirley W. Dunn, Editor, Mohican Seminar 1, The Continuance-An Algonquian Peoples Seminar, Selected Research Papers-2000, Albany, New York State Museum.
} 
Jaegers (riflemen), and killed 20 of them in a single action. One account notes that 48 Stockbridge Indians were with Captain Nimham's Company at this time. ${ }^{67}$

On August 31, 1778, British Lieutenant Colonel John Simcoe planned an ambush against Captain Nimham's company. As an indication of how successful Captain Nimham had been, Simcoe organized no less than 500 soldiers in his operation, including the famous Banister Tarleton commanding British Dragoons; British Grenadiers, Hessian Jaegers, and Loyalist Rangers and Light Infantry. Simcoe used the Hessian Jaegers that the Mohicans had defeated earlier to lure Captain Nimham's Company down a stone-wall lined road, with the German riflemen retreating to the south as if they had been defeated. When the Stockbridge Company had fully entered the ambush, the Jaegers turned and stopped their faked "retreat," the British Grenadiers and Loyalist Rangers fell on both of their flanks, and Tarleton's Dragoons circled around to the rear and cut off the Indians' retreat. The Mohicans fought desperately and courageously, but were surrounded and outnumbered. In the ensuing fight nearly 20 of the Stockbridge Mohicans were killed, including Captain Nimham and his son. The exact number of Indian casualties is unknown. They remain on the battlefield today in unknown graves. The battlefield is now located at Van Courtland Park, the Bronx. Subsequently the company was disbanded, and because of their heavy casualties the surviving members of the company were permitted to return home.

The Stockbridge Munsee Nation and the United States Army have a tradition of serving together to defend our freedoms since 1756. And the United States of America and the Stockbridge Mohicans have been allies since the first days of the American Revolution.

\footnotetext{
${ }^{67}$ Lieutenant Colonel John G. Simcoe, 1844, Simcoe's Military Journal, A History of the Operations of a Partisan Corps Called the Queen's Rangers during the American Revolution, Bartlett \& Welford, page 83; Joseph P. Tustin, 1979, Diary of the American War, A Hessian Journal by Captain Johann Ewald, Field Jager Corps, Yale University Press, page 143.
} 


\section{Consultation with Federally Recognized Tribes}

For West Point's consulting purpose, starting with a present "thread" and tracing it back as far as possible in the fabric of history may be the most efficient way to determine which Federally recognized tribes have possible ties to the USMA. There are three Federally recognized tribes with possible ties: Delaware, Mohawk, and Mohican.

Currently, the Delaware Nation maintains an indirect involvement through the Stockbridge-Munsee Community of Mohican Indians of Wisconsin. As discussed in Chapter 3, research suggests that early inhabitants of the USMA area were Munsee speakers that split off from the Lenape/Delaware and settled along the Hudson River as "River Tribes." Representatives from the Stockbridge-Munsee Community of Mohican Indians of Wisconsin meet regularly with Delaware Nation representatives to discuss matters of common interest. This modern relationship is based on their joint history.

The Mohawk is one of the five original members of the Iroquois League or Confederacy. Known among themselves as the Haudenosaunee (People of the Long House), the Iroquois Confederacy is not limited by modern boundaries, but spans from the United States into Canada. Unity of the Iroquois Nations has grown even stronger in recent decades. Consequently, matters of importance are brought before the Iroquois Confederacy for discussion and decision. The Council of Chiefs is the traditional council for the Haudenosaunee. The St. Regis Mohawk is the Federally recognized tribe in the United States, but is only one of eight Mohawk communities in the United States and Canada that comprise the Mohawk Nation of the Haudenosaunee (their name for the Iroquois Confederacy).

The Stockbridge-Munsee Community of Mohican Indians is the only Federally recognized tribe that incorporates Mohican in its national name. Again this reflects the community's history of dispersal and commingling. 
Going back in time to when the USMA, the oldest continuously occupied military post in the United States, was selected by George Washington and its fortifications were designed (in 1778), Mohicans from the Indian mission village of Stockbridge, Massachusetts, had fought in the Army. They fought during the first years of the Revolutionary War from the siege of Boston to Burgoyne's invasion of 1777.68 During the first half of 1778 more than 100 Native American men were serving in the Continental Army. The Stockbridge Mohicans were the largest contingent. ${ }^{69}$ Eventually, peoples of various bands from several tribes that had created a community at Stockbridge, Massachusetts, moved west, settling in Wisconsin, and becoming the Stockbridge Munsee Community in Shawano County near Bowler, Wisconsin.

General Washington had selected West Point for a fortified site because it was located on high ground above a narrow "S" curve in the Hudson River, allowing control of river traffic. During an approximately 150 -year period, climaxing in the mid- $18^{\text {th }}$ century, ${ }^{70}$ when the Mohawk nation controlled the Indian fur trade, they most likely used the site for that same reason. When the USMA began as a fortified site, the Mohawk Nation had been decimated in numbers. They had retreated to a restricted area of their powerful Iroquois Confederacy in the United States, moved to Canada, or scattered among villages of mixed Indian populations west of New York. Thereafter, European settlers and traders controlled the Hudson River and surrounding lands.

The Mohicans fighting in the Continental Army included men from Norwich and Stockbridge. In the $17^{\text {th }}$ century some New England Algonquian peoples took refuge in the Hudson River Valley and mingled with the Mohicans in residence there, but by then some Mohicans were moving east to the Housatonic Valley to escape land

\footnotetext{
${ }^{68}$ Richard S. Walling, 2004b, “Patriot’s Blood: Washington’s Indian Company of 1778,” in Shirley W. Dunn, Editor, Mohican Seminar 1, The Continuance-An Algonquian Peoples Seminar, Albany, New York State Museum.

${ }^{69}$ Patrick Frazier, 1992, The Mohicans of Stockbridge. University of Nebraska Press, Lincoln.

${ }^{70}$ Carse, 1943.
} 
pressures. ${ }^{71}$ By 1778 when fortifications at the USMA were built, perhaps the only remnants of the Mohicans and Munsee-speaking River Tribes remaining in the area were single families, or members of a religious denomination or descendants intermarried with early colonial settlers. ${ }^{72}$ Most were living in pauperized conditions. ${ }^{73}$ Today's Stockbridge-Munsee Band of Mohican Indians includes descendants of early bands of Munsee speakers and Mohicans that joined to create the original Stockbridge community in Massachusetts. When the Stockbridge community finally settled in Wisconsin, remnant families continued to join the community.

By the time documents pertaining to the USMA area were being recorded, major shifts in Indian populations had already occurred. European confusion on American Indian kinship ties, land use, fluctuating band composition, and migration tends to obscure connections between written history, oral traditions, and the archeological record. The existing archeological record at the USMA not only is limited, but also cannot be connected to tribal names recognized today. Consequently, the USMA consulting relationships will reflect a relatively short period of time without the extensive depth of thousands of years of human activity suggested in the archaeological record. Furthermore, that period of time reflected was exceeding tumultuous with rapid changes occurring among Indian bands, their political affiliations, and even their areas of resource use. Given these circumstances, consultation with current Federally recognized tribes may be subject to change as additional tribes may be recognized. As is always the case, close attention should be paid to American Indian interpretations and interactions on who should be consulted and to what degree on consulting issues.

\footnotetext{
${ }^{71}$ Richard S. Walling, 2004c, "Death in the Bronx, the Stockbridge Indian Massacre, August 1778” accessed on-line at http://www.americanrevolution.org/ind3.html on October 28, 2004.

${ }^{72}$ Source: "Receipt Book of Brigade Quartermaster Abraham Tuckerman, 1st Massachusetts Brigade, April 26- November 26, 1781.” American Antiquarian Society, Worcester, Massachusetts. Transcribed by Douglas R. Cubbison, USMA. Written on note inside of the cover: "Gave the Indian woman to wash 1 plain shirt, 1 ruff shirt, 2 stocks, 1 pr breeches, September 20, 1781.” His regiment was across the Hudson River (in Peekskill, then "Phillipsborough" [now Garrison]) during this timeframe.

${ }^{73}$ Tyndall, 2004.
} 


\section{Federally Recognized Tribes}

The USMA will initiate consultations with the following Federally recognized tribes:

\section{Stockbridge-Munsee Band of Mohican Indians}

President Robert Chicks

Cultural Preservation Office

Sherry White

N 8476 Mo He Con Nuck Road

Bowler, WI 54416

715-793-4111

Fax: 715-793-1307

\section{Mohawk}

Council of Chiefs

518-358-3381

Curtis Lazore

Haudenosaunee Cultural Resource Protection Program

Post Office Box 366

Rooseveltown, NY 13683

518-358-6141

\section{St. Regis Mohawk Tribe}

412 State Route 37

Akwesasne, NY 13655

$518-358-2272$

Fax: 518-358-4519

\section{Other Interested Parties}

Federal law states that the USMA can choose to consult with interested parties.

This provides the installation with the opportunity to consult with Native American groups other than the Federally recognized tribes mentioned above. The USMA intends to consult with the full range of Native American organizations with an interest in the Hudson Highlands. 
The Mohawk Community of Kanatsiohareke has recently been established in the Mohawk Valley, near Johnstown. This community has not yet achieved status as a Federally Recognized Native American Community.

Kanatsiohareke Mohawk Community 4934 State Highway 5

Fonda, NY 12068

518-673-5356

Fax: 518-673-5575.

http://fiascofarms.com/kanat/, http://www.mohawkcommunity.com/).

\section{Consultation Protocol}

The USMA will develop Memorandums of Agreement/Understanding with each individual nation, and specific consultation processes will be developed for each nation. The following is intended as a general consultation protocol and will serve as a starting point for developing focused consultation processes for each nation.

The following was prepared by Bobbi Rahder of Bobbi Rahder Consulting, Lawrence, Kansas, and is based on The American Indian Mind in a Linear World: American Indian Studies \& Traditional Knowledge by Donald L. Fixico and Power and Place:

Indian Education in America by Vine Deloria, Jr., and Dan Wildcat. It is taken from an unpublished report prepared for the U.S. Army Engineer Research and Development Center, Construction Engineering Research Laboratory, 15 April 2004.

Provide food for consultants and their families. Understand that they will be traveling to the consultation site and will need sustenance. Understand also, that children may come along with the families even to meetings.

Understand how everything ties together — social, spiritual, political, past, present, and future. 
Start the meeting with prayer by elders. They may want to smudge the room with cedar or sage. They should be compensated with food and a consultant fee or gift such as tobacco.

Don't interrupt. It is considered very rude to interrupt. Let the conversation flow at its natural pace. "The point of knowledge or an idea may not be apparent at the moment of its introduction, but with patience, the message becomes clear. Sometimes, this realization takes several minutes, days, or even years. Its importance or relevance derives from the realization or with the help of a wiser person or special person who is gifted to interpret insightful experiences such as dreams or visions." 74

Indian thinking is "seeing” and "listening." “... (L)istening involves hearing and realizing as a receiver while understanding the objective of seeing. ... "seeing" in this way involves trying to understand the significance of relationships ... Without listening, seeing only provides images to the mind, with limited information and hearing sounds adds substance or more pertinent knowledge to the visual experience."75

Understand the importance of oral tradition to Native people. "Elders tell stories in the oral tradition of tribes, where it was equally important to listen to the story as well as tell the story. Both storyteller and listener engage in reviving an experience of the past ... to the present. Both tenses of time blur, becoming one and the same."76

"Silence is the test for patience. In silence, two people are still engaged in the same experience of concentrating on the same item or piece of knowledge. In this way, learning to deal and function with silence is a means for securing one's thoughts and confirming one's beliefs." 77

\footnotetext{
${ }^{74}$ Donald L. Fixico, 2003, The American Indian Mind in a Linear World: American Indian Studies and Traditional Knowledge, Routledge, New York and London, p 3.

${ }^{75}$ Fixico, 2003, p 4.

${ }^{76}$ Fixico, 2003, p 5.

${ }^{77}$ Fixico, 2003, p 5.
} 
Circular thinking in a linear world - taking into account the environment, relationships, metaphysical. "Indian thinking" is "seeing" things from a perspective emphasizing that circles and cycles are central to the world and that all things are related within the universe. Indian people see things from the perspective "that involves human beings, animals, plants, the natural environment, and the metaphysical world of visions and dreams and spirits."78 "The circular approach assures that everyone understands and that all is considered, thereby increasing the chance for harmony and balance in the community and with everything else."79

Sometimes you are not supposed to ask why. "Sometimes the problem is unsolvable and that is part of accepting the Natural Order of things." 80 The primary focus of creation stories of many tribes placed human beings as among the last creatures who were created and as the youngest of the living families. "We were given the ability to do many things, but not specific wisdom about the world. So our job was to learn from other, older beings and to pattern ourselves after their behavior. We were to gather knowledge, not dispense it."81 "Indian knowledge is designed to make statements that adequately describe the experience or phenomenon. That is to say, they include everything that is known about the experience even if no firm conclusions are reached ... It is permissible within the Indian context to admit that something mysterious remains after all is said and done."82

"The universe is alive. The Universe is personal and therefore, must be approached in a personal manner." 83

"American Indians have a long history of rejecting abstract theologies and metaphysical systems in place of experiential systems properly called

\footnotetext{
${ }^{78}$ Fixico, 2003, p 2.

${ }^{79}$ Fixico, 2003, p 16.

${ }^{80}$ Fixico, 2003, p 17.

${ }^{81}$ Vine Deloria, Jr., and Dan Wildcat, 2001, Power and Place: Indian Education in America. Fulcrum Resources: Colorado, p 60.

82 Deloria and Wildcat, 2001, p 127.

${ }^{83}$ Deloria and Wildcat, 2001, p 23.
} 
indigenous - indigenous in the sense that people historically and culturally connected to places can and do draw on power locate din those places. Stated simply, indigenous means 'to be of a place." 84

A respect for the spiritual nature of Native Americans is essential in any consultation with Native people. "Today the irreconcilable conflict between meaning/values and knowledge/facts in Western metaphysics is obvious. This is clearly demonstrated in the inability of Western legal institutions to grasp American Indian and Alaska Native claims that some places on the planet possess a degree of sacredness that precludes treatment as real estate, private property, or public lands." ${ }^{5}$ "The incredible gulf between Western and indigenous metaphysics is best summed up as follows: in the Western context metaphysics became a study for philosophers; in indigenous communities metaphysics would be understood as the basis for living well attentively, respectfully, and responsibly — in this world." 86

\footnotetext{
${ }^{84}$ Deloria and Wildcat, 2001, p 31.

${ }^{85}$ Deloria and Wildcat, 2001, p 48.

${ }^{86}$ Deloria and Wildcat, 2001, p 52.
} 


\section{Bibliography}

Becker, Marshall Joseph

1993 "The Lenape and Other "Delawarean" Peoples at the Time of European Contact:

Population Estimates Derived from Archaeological and Historical Sources." Bulletin and

Journal of Archaeology for New York State, 105.

Brasser, Louis

1978 "Mahican." Handbook of North American Indians, edited by Bruce Trigger, Volume 15. Smithsonian Institution Press, Washington, DC.

Brinton, Daniel G.

1885 The Lenape and Their Legends; with Complete Text and Symbols of the Walam Olum, a New Translation, and an Inquiry into its Authenticity. Library of Aboriginal American Literature 5, Philadelphia.

Carse, Mary Rowell 1943 The Mohawk Iroquois. Master of Arts Thesis, Anthropology Department, Yale University.

Cassedy, Daniel, P. Webb, A. Dowd, J. Jones, C. Cobb, S. Dillon, M. Reinbold, and T. Millis 1993 Iroquois Gas Transmission System, Phase III Archaeological Data Recovery Report, Volume 2, The Valley Region. Garrow and Associates, Inc., Atlanta, GA.

Curtin, Edward V. 1987 John Robinson I Historic Site and John Robinson II Prehistoric Site. Archaeological Data Recovery Report, PIN 8914.16.101. New York State Museum, Albany, NY.

Deloria, Vine, Jr., and Dan Wildcat 2001 Power and Place: Indian Education in America. Fulcrum Resources: Colorado, p 60.

DeVoe, Thomas F. 1880 "The Massacre of the Stockbridge Indians, 1778" Magazine of American History V, no. 3, September 1880.

Dunn, Shirley W.

1994 The Mohicans and Their Land 1609-1730. Purple Mountain Press, Fleischmanns, New York.

Eisenberg, Leonard 1980 A Cultural Resources Survey of the Proposed Lake Frederick Drop Zone and Indoor Athletic Facility Sites, U.S. Military Academy, West Point, New York. Report on file at the United States Military Academy, West Point.

Feister, Lois M.

1973 "Linguistic Communication between the Dutch and Indians in New Netherland, 16091664," Ethnohistory 20, Issue 1, Winter 1973. 
Fenton, William N.

1961 "Iroquoian Culture History: A General Evaluation in Symposium on Cherokee and Iroquois Culture," William N. Fenton and John Gulick, eds. Bureau of American Ethnology Bulletin 180. Washington, DC.

Fenton, William N. 1978 "Northern Iroquoian Culture Patterns," in "Northeast," edited by Bruce G. Trigger, pp. 296-321, in Handbook of North American Indians, vol. 15, William C. Sturtevant, general editor. Smithsonian Institution, Washington, DC.

Fiedel, Stuart J.

1987 "Algonquian Origins: A Problem in Archeological-Linguistic Correlation." Archaeology of Eastern North America, 15:1-11.

Fiedel, Stuart J.

1991 "Correlating Archaeology and Linguistics: The Algonquian Case." Man in the Northeast, 41:9-32.

Fiedel, Stuart J.

1999 "Algonquians and Iroquoians: Taxonomy, Chronology, and Archaeological Implications," in Taming the Taxonomy: Toward a New Understanding of Great Lakes Archeology, edited by R. F. Williamson and E. M. Wafts, pp. 193-204. The Ontario Archeological Society, Inc. and Eastend Books, Toronto.

Fiedel, Stuart J.

2001 "What Happened in the Early Woodland?" in Archaeology of Eastern North America 29:101-142.

Fixico, Donald L.

2003 The American Indian Mind in a Linear World: American Indian Studies and Traditional Knowledge, Routledge, New York and London.

Fraizer, Patrick

1992 The Mohicans of Stockbridge. University of Nebraska Press, Lincoln.

Patrick Frazier, The Mohicans of Stockbridge, pp 209-210

Funk, Robert E. 1976 Recent contributions to Hudson Valley Prehistory. New York State Museum Memoir 22, Albany, NY.

Funk, Robert E., George R. Walters, William F. Ehlers, Jr., John E., Guilday, and G. Gordon Connally 1969 "The Archeology of Dutchess Quarry Cave, Orange County, New York," Pennsylvania Archeologist 39(1-4):7-22.

Funk, Robert E., George R. Walters, and William F. Ehlers, Jr.

1969 "A Radiocarbon Date for Early Man from the Dutchess Quarry Cave," New York State Archaeological Association Bulletin 46 (July):19-21. Rochester, NY.

Funk, Robert E., Donald W. Fisher, and Edgar M. Reilly, Jr. 1970 "Caribou and Paleo-Indian in New York State: A Presumed Association," American Journal of Science 268(2):181-186. 
Gehring, Charles T. and William A. Starna

1991 "Dutch and Indians in the Hudson Valley: The Early Period," The Hudson Valley

Regional Review.

Goddard, Ives

1978 "Central Algonquian Languages," in Handbook of North American Indians, Volume

15, The Northeast, edited by B.G. Trigger, Smithsonian Institution, Washington, DC.

Griffin, James B.

1961 "Some Correlations of Climatic and Cultural Change in Eastern North American

Prehistory," Annals of the New York Academy of Sciences 95:710-717. New York.

Grumet, Robert S.

1995 Historic Contact. University of Oklahoma Press, Norman and London.

Guilday, John E.

1969 "A Possible Caribou-Paleo-Indian Association from Dutchess Quarry Cave, Orange

County, New York.” New York State Archaeological Association Bulletin 44:24-29. Rochester.

Guldenzopf, David B.

1986 The Colonial Transformation of Mohawk Iroquois Society, State University of New York at Albany: PhD Thesis.

Hart, John P. and Hetty Jo Brumbach

2003 “The Death of Owasco.” American Antiquity 68(4):737-752.

Hauptman, Laurence M.

1978 "The Dispersal of the River Indians: Frontier Expansion and Indian Dispossession in the Hudson Valley" in Laurence M. Hauptman and Jack Campisi, editors, Neighbors and Intruders: An Ethnohistorical Exploration of the Indians of Hudson's Rivers, Ottawa: National Museums of Canada.

Heckewelder, John G.E.

1819 "An Account of the History, Manners, and Customs of the Indian Nations, Who Once Inhabited Pennsylvania and the Neighbouring States." Transactions of the Committee of History, Moral Science and General Literature of the American Philosophical Society 1. Philadelphia.

Hunt, George, T.

1960 The Wars of the Iroquois: A Study in Intertribal Trade Relations. University of Wisconsin Press, Madison, WI.

Jameson, J.F. (editor)

1909 "Wassenaer's Historical Verhael" in Narratives of New Netherland, 1609-1664. New

York: Charles Scribner's Sons.

Jameson, J.F. (editor)

1090 "Letter of Reverend Jonas Michaelius," in Narratives of New Netherland, 1609-1664.

New York: Charles Scribner's Sons. 
Jennings, Francis

1984 The Ambiguous Iroquois Empire, The Covenant Chain Confederation of Indian Tribes with English Colonies, New York: W. W. Norton \& Company.

Lenig, Donald

1977 "Of Dutchmen, Beaver Hats and Iroquois” in Robert E. Funk and Charles F. Hayes III, editors, Current Perspectives in Northeastern Archaeology, Essays in Honor of William A. Ritchie, Researches and Transactions of the New York State Archaeological Association, Volume 17, no. 1.

Lenig, Wayne 1999 "Patterns of Material Culture During the Early Years of New Netherland Trade," Northeast Anthropology 58, Fall 1999.

Mohawk, John

2004 Indian Country Today, "Indigenous Rights Must Become a Priority," September 22, 2004 Vol 24, No. 15.

Mooney, James

1907 "Delaware," pp 385-387 in Vol 1 of Handbook of American Indians North of Mexico, Frederick W. Hodge, ed. 2 vols. Bureau of American Ethnology Bulletin 30, Washington, DC.

"Receipt Book of Brigade Quartermaster Abraham Tuckerman, 1st Massachusetts Brigade, April 26November 26, 1781.” American Antiquarian Society, Worcester, Massachusetts. Transcribed by Douglas R. Cubbison, USMA.

Richter, Daniel K. 1992 The Ordeal of the Longhouse, The Peoples of the Iroquois League in the Era of European Colonization. Chapel Hill: The University of North Carolina Press.

Ritchie, William A. and Robert E. Funk 1973 Aboriginal Settlement Patterns in the Northeast. New York State Memoir 20, Albany, NY.

Rumrill, Donald A. 1985 "An Interpretation and Analysis of the Seventeenth Century Mohawk Nation: Its Chronology and Movements" The Bulletin and Journal of Archaeology for New York State Archaeological Society 90.

Rumrill, Donald A.

1991 “The Mohawk Glass Trade Bead Chronology: ca. 1560-1785” Beads, Journal of the Society of Bead Researchers 3.

Ruttenber, E.M.

1872 History of the Indian Tribes of Hudson's River, Their Origins, Manners and Customs; Tribal and Sub-Tribal Organizations; Wars, Treaties, Etc., Etc. J. Munsell, Albany, NY.

Schrabisch, Max 1936 "Archaeology of Southern New York." Unpublished manuscript on file at New York State Museum. 
Salomon, Julian Harris

1982 Indians of the Lower Hudson Region, The Munsee. New City, New York: Historical Society of Rockland County.

Schlesier, Karl H.

1976 "Epidemics and Indian Middlemen: Rethinking the Wars of the Iroquois, 1609-1653"

Ethnohistory 23, No. 2 (Spring 1976).

Simcoe, Lieutenant Colonel John G.

1844 Simcoe's Military Journal, A History of the Operations of a Partisan Corps Called the

Queen's Rangers during the American Revolution, Bartlett \& Welford

Snow, Dean R.

1994 The Iroquois. Cambridge, Massachusetts and Oxford, United Kingdom: Blackwell Publishers.

Snow, Dean R. and Kim M. Lanphear

1988 "European Contact and Indian Depopulation in the Northeast: The Timing of the First Epidemics.” Ethnohistory 35, no. 1, Winter 1988.

Swanton, John R.

1952 The Indian Tribes of North America. Smithsonian Institution Bureau of American Ethnology Bulletin 145.

Sykes, C.M.

1980 "Swidden Horticulture and Iroquoian Settlement." Archaeology of Eastern North

America 8:45-52.

Tanner, Helen Hornbeck

1979 "Coocoochee: Mohawk Medicine Woman." American Indian Culture and Research Journal 3(3):23-41.

Tompkins, R. Curt and Laurie DiMaria

1979 "Excavations at Muddy Brook Rockshelter, 1975-1976: A Progress Report." New York State Archaeological Association Bulletin 75:58-63.

Trelease, Allen W.

1060 Indian Affairs in Colonial New York: The Seventeenth Century.

Trigger, Bruce G.

1971 “The Mohawk-Mahican War (1624-1628): The Establishment of a Pattern” Canadian Historical Review 52, No 3, September 1971.

Trigger, Bruce G.

1978 "Early Iroquoian Contacts with Europeans," in Northeast, edited by Bruce G. Trigger, pp. 344-356. Handbook of North American Indians, vol. 15, William C. Sturtevant, general editor. Smithsonian Institution, Washington, D.C.

Tustin, Joseph P.

1979 Diary of the American War, A Hessian Journal by Captain Johann Ewald, Field Jager Corps, Yale University Press. 
Tyndall, Monique J.

2004 "Ridge Hill Yonkers, New York: Study of the Weckquasgeek Chieftaincy and the Present Site Known as "RidgeHill”. Unpublished manuscript. Cultural Preservation Office, Stockbridge-Munsee Band of Mohican Indians.

Vernon, Howard

1978 "The Dutch, The Indians and the Fur Trade in the Hudson Valley, 1609-1664" in Laurence M. Hauptman and Jack Campisi, editors, Neighbors and Intruders: An Ethnohistorical Exploration of the Indians of Hudson's Rivers, Ottawa: National Museums of Canada.

Walling, Richard S.

2004a “Nimham's Indian Company of 1778: The Events Leading up to the Stockbridge Massacre of August 31, 1778" in Shirley W. Dunn, Editor, Mohican Seminar 1, The Continuance-An Algonquian Peoples Seminar, Selected Research Papers-2000. Albany, New York State Museum.

Walling, Richard S.

2004b "Patriot's Blood: Washington's Indian Company of 1778," in Shirley W. Dunn, Editor, Mohican Seminar 1, The Continuance-An Algonquian Peoples Seminar, Albany, New York State Museum.

Walling, Richard S.

2004c "Death in the Bronx, the Stockbridge Indian Massacre, August 1778" accessed on-line at http://www.americanrevolution.org/ind3.html on October 28, 2004.

Weslager, Clinton A.

1972 The Delaware Indians: A History. Rutgers University Press, New Brunswick, New Jersey.

White, Julia

Woman Spirit, Coocoochee - Mohawk, http://www.meyna.com/mohawk2.html. Accessed September 2005. 


\section{Appendix A: Related Federal Laws, Orders, and Information}

- Native American Graves Protection and Repatriation Act of 1990 (NAGRPA) [25 USC 3001-1013].

- American Indian Religious Freedom Act of 1978 (AIRFA) [42 USC 1996].

- Presidential Executive Order 13007, Indian Sacred Sites (24 May 1996).

- Executive Memorandum, "Government to Government Relations with Native American Tribal Governments" (29 April 1994).

- Presidential Executive Order 13175, "Consultation and Coordination with Indian Tribal Governments" (November 9, 2000).

- Indian Tribal Justice and Legal Assistance Act of 2000 [Public Law 106-559].

- U.S. Environmental Protection Agency, "Working Effectively with Tribal Governments" (August 1996, available at http://www.epa.gov/indian/resource/modules/entire.pdf). 


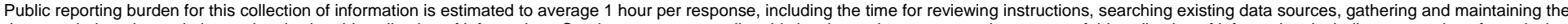

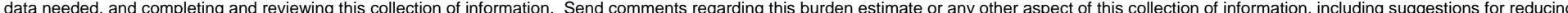

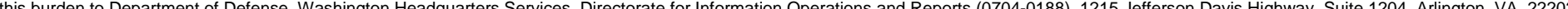

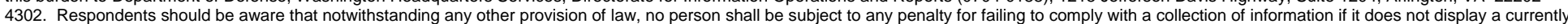
valid OMB control number. PLEASE DO NOT RETURN YOUR FORM TO THE ABOVE ADDRESS

\section{REPORT DATE (DD-MM-YYYY) 04-2006}

4. TITLE AND SUBTITLE

Native American Historic Context for the United States Military Academy:

West Point, New York
3. DATES COVERED (From - To)

5a. CONTRACT NUMBER

5b. GRANT NUMBER

5c. PROGRAM ELEMENT NUMBER

5d. PROJECT NUMBER

MIPR5ECRL50055

5e. TASK NUMBER

5f. WORK UNIT NUMBER

8. PERFORMING ORGANIZATION REPORT NUMBER

ERDC/CERL SR-06-2

U.S. Army Engineer Research and Development Center (ERDC)

Construction Engineering Research Laboratory (CERL)

PO Box 9005

Champaign, IL 61826-9005

\section{SPONSORING I MONITORING AGENCY NAME(S) AND ADDRESS(ES)}

United States Military Academy

Directorate of Housing and Public Works

Building 667 Ruger Road

West Point, NY 10996

10. SPONSOR/MONITOR'S ACRONYM(S) EP\&SD

11. SPONSOR/MONITOR'S REPORT NUMBER(S)

\section{DISTRIBUTION / AVAILABILITY STATEMENT}

Approved for public release; distribution is unlimited.

\section{SUPPLEMENTARY NOTES}

Copies are available from the National Technical Information Service, 5285 Port Royal Road, Springfield, VA 22161.

\section{ABSTRACT}

The United States Military Academy (USMA) is required by Federal laws, Executive Orders, and implementing regulations to conduct consultations with Native American tribes under specific circumstances. This historic context was prepared to support the preparation of a Native American Consultation program at the USMA by identifying the appropriate Indian tribes with whom consultation should take place.

This report discusses historic periods and possible archeological sites near the USMA. It contains a brief history of various Native American nations that may have been living in or using the West Point vicinity and the Hudson Highlands at initial contact with Europeans and discusses early interactions between Europeans and the Native American nations in the Hudson Valley. This report also specifically identifies the appropriate Native American Federally recognized tribes and communities, and other appropriate Native American organizations and entities with which the USMA should consult. Recommendations for the consultation protocol are included.

\section{SUBJECT TERMS}

Native American

U.S. Military Academy

16. SECURITY CLASSIFICATION OF:

\section{a. REPORT} Unclassified

\section{b. ABSTRACT}

Unclassified
West Point, NY

American Indian

NSN 7540-01-280-5500 cultural resources management archaeological research

\begin{tabular}{|c|c|c|} 
& $\begin{array}{c}\text { 17. LIMITATION } \\
\text { OF ABSTRACT }\end{array}$ & $\begin{array}{c}\text { 18. NUMBER } \\
\text { OF PAGES }\end{array}$ \\
\cline { 1 - 1 } $\begin{array}{c}\text { C. } \text { THIS PAGE } \\
\text { Unclassified }\end{array}$ & SAR & 44
\end{tabular}

19a. NAME OF RESPONSIBLE PERSON

19b. TELEPHONE NUMBER (include area code) (217) 352-6511

Standard Form 298 (Rev. 8-98)

Prescribed by ANSI Std. 239.18 